\title{
traT Gene Sequences, Serum Resistance and Pathogenicity-related Factors in Clinical Isolates of Escherichia coli and Other Gram-negative Bacteria
}

\author{
By M. A. MONTENEGRO, ${ }^{1} \dagger$ D. BITTER-SUERMANN ${ }^{2}$ J. K. TIMMIS, ${ }^{1}$ \\ M. E. AGÜERO,$^{3}$ F. C. CABELLO ${ }^{3}$ S. C. SANYAL ${ }^{4}$ AND K. N. TIMMIS ${ }^{1 *}$ \\ ${ }^{1}$ Department of Medical Biochemistry, University of Geneva, Switzerland \\ ${ }^{2}$ Institute of Medical Microbiology, University of Mainz, Federal Republic of Germany \\ ${ }^{3}$ Department of Microbiology, New York Medical College, Valhalla, NY, USA \\ ${ }^{4}$ Department of Microbiology, Banaras Hindu University, Varanasi, India
}

(Received 26 October 1984; revised 28 December 1984)

\begin{abstract}
The R6-5 plasmid-specified outer membrane protein, TraT protein, has previously been shown to mediate resistance to bacterial killing by serum. Colony hybridization with a 700 bp DNA fragment carrying most of the $\operatorname{traT}$ gene was used to examine the prevalence of $\operatorname{traT}$ in Gramnegative bacteria, particularly strains of Escherichia coli, isolated from clinical specimens. traT was found in isolates of E. coli, Salmonella, Shigella and Klebsiella, but not in Pseudomonas, Aeromonas or Plesiomonas, nor in the few isolates of Enterobacter, Proteus, Acinetobacter, Citrobacter, Serratia or Yersinia that were examined. It was detected in a significantly higher proportion of the $E$. coli strains isolated from the blood of patients with bacteraemia/septicaemia or from faeces of patients with enteric infections (50-70\%) than in that of strains isolated from normal faeces $(20-40 \%)$. The incidence of $t r a T$ in strains isolated from cases of urinary tract infections was variable. $t r a T$ was found to be frequently associated with production of the $\mathrm{K} 1$ capsule and with the carriage of ColV plasmids, but not with the carriage of $R$ plasmids, nor with serum resistance or the production of haemolysin.
\end{abstract}

\section{INTRODUCTION}

It is well established that normal animal serum is bactericidal for most types of bacteria (for recent review see Taylor, 1983). This bactericidal activity, the principal component of which is complement, is generally considered to be an important host defence against bacterial infections. As a consequence, resistance to serum killing is regarded as an important virulence property of invasive bacteria. Consistent with this notion is the fact that Escherichia coli strains isolated from the blood of patients with bacteraemia/septicaemia are more likely to be resistant to serum than are those isolated from the faeces of healthy individuals (Roantree \& Rantz, 1960; Vosti \& Randall, 1970). Moreover, serum resistant $E$. coli strains are more often associated with shock and death in bacteraemic patients than are serum sensitive strains (McCabe et al., 1978).

Several distinct components of the bacterial cell surface have been implicated in serum resistance (for recent reviews, see Taylor, 1983; Timmis et al., 1985), including the O-side-chains of certain types of lipopolysaccharide (LPS) (Taylor, 1976; Moll et al., 1980; Joiner et al., 1982; Goldman et al., 1984), capsular antigens (Gemski et al., 1980; Timmis et al., 1981; Agüero \& Cabello, 1983), and surface proteins (Hildebrandt et al., 1978; Moll et al., 1980; Munn et al., 1982). In some instances, resistance does not result from a single attribute but rather from the combined effects of two or more cell components.

$\dagger$ Present address: Bundesgesundheitsamt, West Berlin, FRG.

Abbreviation: UTI, urinary tract infection. 
The genetic determinants of some serum resistance factors of $E$. coli have been shown to be located on conjugative plasmids : the iss gene is carried by some ColV plasmids (Williams Smith, 1974; Binns et al., 1979) whereas the traT gene, which encodes a major outer membrane protein, is carried by a variety of IncF plasmids (Timmis et al., 1979; Moll et al., 1980). These determinants have been cloned and subjected to genetic and functional analyses (Timmis et al., 1979; Moll et al., 1980; Timmis et al., 1981; Ogata et al., 1982; C. Parada, M. E. Fernandez, M. M. Binns \& F. C. Cabello, unpublished).

The traT gene product is a major outer membrane protein having an apparent molecular weight of 25000 (Achtman et al., 1978; Moll et al., 1980), and is present in natural isolates of $E$. coli at 3000-10000 copies per cell (Agüero et al., 1984; Bitter-Suermann et al., 1984). It probably exists in the outer membrane as a lipoprotein (Perumal \& Minkley, 1984) associated noncovalently with peptidoglycan (Manning et al., 1980), and appears to be highly exposed on the cell surface, at least in cells of $E$. coli $\mathrm{K} 12$ (Timmis et al., 1981). In addition to its ability to confer upon host bacteria resistance to killing by complement, TraT protein in combination with the product of an adjacent gene, traS, mediates the property of surface exclusion (Achtman et al., 1977), the reduced ability of a strain carrying a conjugative plasmid to act as a recipient when mated with a donor strain carrying a related plasmid.

The mechanism by which TraT protein mediates resistance to complement has not yet been elucidated, although the possibility that it acts by inactivation of one or more complement components seems to have been ruled out (Timmis et al., 1981). Studies on the binding of complement components to isogenic $\mathrm{rraT}^{+}$and $\operatorname{traT}$ cells have failed to detect any significant differences in the amounts of individual components bound when bacteria are suspended in serum. Thus, the serum resistance property of $\mathrm{traT}^{+}$cells would seem not to result from a TraT protein-mediated reduction in the binding of complement, but rather by an interference with the correct assembly or functioning of the complement membrane attack complex. The finding that the presence of TraT protein in bacteria suspended in serum results in an altered distribution of C 3 b bound to the cell surface (Agüero et al., 1984) would suggest that TraT protein may modify sites on the cell surface that are sensitive to membrane attack complex.

It should be noted that TraT protein also reduces the susceptibility of bacteria to phagocytosis by peritoneal macrophages (Agüero et al., 1984) and increases to a limited but significant extent the pathogenicity of an E. coli strain for a mouse infection model (L. DeLuca \& F. C. Cabello, unpublished observations).

A crucial aspect of any potential pathogenesis factor is its prevalence among pathogenic and non-pathogenic microbes. In this regard, the availability of cloned genes of such factors facilitates an analysis of their epidemiology in clinical isolates. In this communication, we report

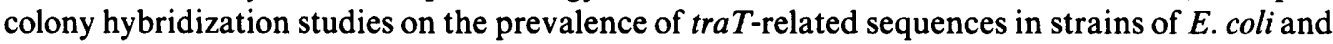
other Gram-negative bacteria isolated from cases of septicaemia (sepsis), urinary tract infection (UTI) and enteric disease, and from faeces of healthy individuals. Furthermore, we have investigated the association of $\operatorname{traT}$ with several other putative pathogenesis factors of $E$. coli.

\section{METHODS}

Bacterial strains. Bacterial isolates from patients or healthy individuals were obtained from the diagnostic laboratories of the Universities of: Mainz, FRG; Berlin, FRG; Geneva, Switzerland; Banaras, India; New York, USA; and Boston, USA.

Plasmids. The multiple antibiotic resistance plasmid R6-5 has been described previously (Timmis et al., 1978). The pACYC184 hybrid plasmid pKT107 (Timmis et al., 1979; Moll et al., 1980), which carries the R6-5 traT gene, was used as the source of the $\operatorname{tr} T$ gene probe. Plasmids belonging to the different incompatibility groups listed in Table 1 were obtained from N. Datta (Hammersmith Hospital, London, UK). Plasmid DNA was purified and subjected to fragmentation with restriction enzymes, and the fragments thereby generated were analysed by electrophoresis on $0.7 \%$ or $0.8 \%$ agarose gels in Tris/borate buffer, as described previously (Timmis et al., 1978; Andres et al., 1979). Plasmid DNA from natural isolates was isolated by the method of Kado \& Lui (1981).

Enzymes. Restriction enzymes BstEII, EcoRI and HindIII were purchased from New England Biolabs and used according to the conditions recommended by the supplier. DNA polymerase I and DNAase I used in the nick translation reaction were obtained from Boehringer-Mannheim. 
Table 1. Occurrence of sequences homologous to the traT gene in plasmids belonging to different incompatibility groups

\begin{tabular}{lccllc}
\multicolumn{1}{c}{ Plasmid } & $\begin{array}{c}\text { Incompatibility } \\
\text { group }\end{array}$ & traT & \multicolumn{2}{c}{ Plasmid } & $\begin{array}{c}\text { Incompatibility } \\
\text { group }\end{array}$ \\
RA1 & A & - & R144, R144-3, R64drd-11 & I $\alpha$ & - \\
R16 & B -0 & - & R621a & I $~$ & - \\
R40a & C & - & R471a & L & - \\
R386 & FI & + & N3 & N & - \\
R1, R6-5, R100, R538-1 & FII & + & R478 & S & - \\
R124 & FIV & + & S-a & W & - \\
R27 & H1 & - & R6K & X & -
\end{tabular}

DNA probe. The hybrid plasmid pKT107 consists of a $6 \mathrm{~kb}$ EcoRI fragment of the multi-resistant plasmid R6-5 linked to vector plasmid pACYC184 (Timmis et al., 1979; Moll et al., 1980). Digestion of this plasmid with BstEII endonuclease generates two fragments, a large one and a $700 \mathrm{bp}$ fragment which contains about $90 \%$ of the $t r a T$ gene (Moll et al., 1980; Ogata et al., 1982). This latter fragment is the traT-specific probe used in all of the experiments described below. It was isolated by electroelution (Dretzten et al., 1981) from $0.8 \%$ agarose gels, following electrophoresis of BstEII-cleaved pKT107 DNA, and was labelled with [ $\alpha_{-32}$ P]dCTP (Amersham) by nick translation (Rigby et al., 1977).

Hybridization experiments. Colony hybridization was done essentially as described by Grunstein \& Hogness (1975) and Moseley et al. (1980). The hybridization conditions were $50 \%$ (v/v) formamide $/ 5 \times \mathrm{SSC}$ at $37^{\circ} \mathrm{C}$ for $18 \mathrm{~h}(1 \times \mathrm{SSC}$ is $0.15 \mathrm{M}-\mathrm{NaCl}, 0.015 \mathrm{M}$-trisodium citrate, $\mathrm{pH} 7 \cdot 0)$. Filters were washed in $5 \times \mathrm{SSC}$ at $65^{\circ} \mathrm{C}$, then in $2 \times \mathrm{SSC}$ at room temperature, and were then exposed to X-ray films.

Southern blotting was done essentially as described by Southern (1975). The hybridization conditions were $2 \times$ SSC at $65^{\circ} \mathrm{C}$ for $18 \mathrm{~h}$. Prior to autoradiography, the filters were washed successively in $2 \times$ SSC, $1 \times$ SSC, and $0.2 \times \mathrm{SSC}$, each solution at $65^{\circ} \mathrm{C}$ and containing $0.1 \% \mathrm{SDS}$.

Serum resistance, and production of colicin $V$ and haemolysin. The procedure followed for determination of bacterial resistance to killing by pooled rabbit serum was the viable count method described in Moll et al. (1979), except that equal volumes of serum and bacterial suspension were mixed to give a final serum concentration of $50 \%(\mathrm{v} / \mathrm{v})$, and that the period of incubation of bacteria in serum was $120 \mathrm{~min}$. Detection of the production of colicin V and haemolysin was as previously described (Agüero et al., 1983).

\section{RESULTS}

Specificity of the traT DNA probe and prevalence of the traT gene on plasmids of different incompatibility types

The specificity of the DNA probe was investigated by Southern blot analysis of restriction endonuclease-cleaved and fractionated DNAs of plasmids belonging to different incompatibility groups. Figure 1 shows an autoradiograph of a blot of several different plasmids probed with the $700 \mathrm{bp}$ fragment of pKT107. The probe hybridized to large HindIII fragments of plasmids R386 (IncFI) and R124 (IncFIV), in addition to the expected $6 \mathrm{~kb} E c o$ RI fragment of plasmid R6-5 (IncFII) and the small BstEII fragment of pKT107. In contrast, no hybridization was observed to any HindIII fragment of plasmid R6K (IncX). Similar analysis of plasmids belonging to other incompatibility groups showed that none of them contain sequences homologous to the traT gene (Table 1). These experiments indicate that the probe DNA is highly specific and that the traT gene is carried only by the IncF plasmids. The traT gene was initially reported as being part of the transfer operon of the F plasmid (IncFI) (Achtman et al., 1977) but has since also been found in other IncF plasmids (Achtman, 1978; Ogata et al., 1982).

\section{Prevalence of traT gene in non-E. coli Gram-negative clinical isolates}

A bout 300 non- $E$. coli Gram-negative clinical isolates were analysed by colony hybridization for carriage of the traT gene. Homology to the DNA probe was found in isolates of Klebsiella $(22 \%)$, Shigella $(35 \%)$ and Salmonella, particularly Salmonella typhimurium $(95 \%)$, but not in isolates of Citrobacter, Serratia, Enterobacter, Proteus, Acinetobacter, Pseudomonas, Aeromonas, Plesiomonas or Yersinia (Table 2). The limited spectrum of bacteria carrying traT is consistent 


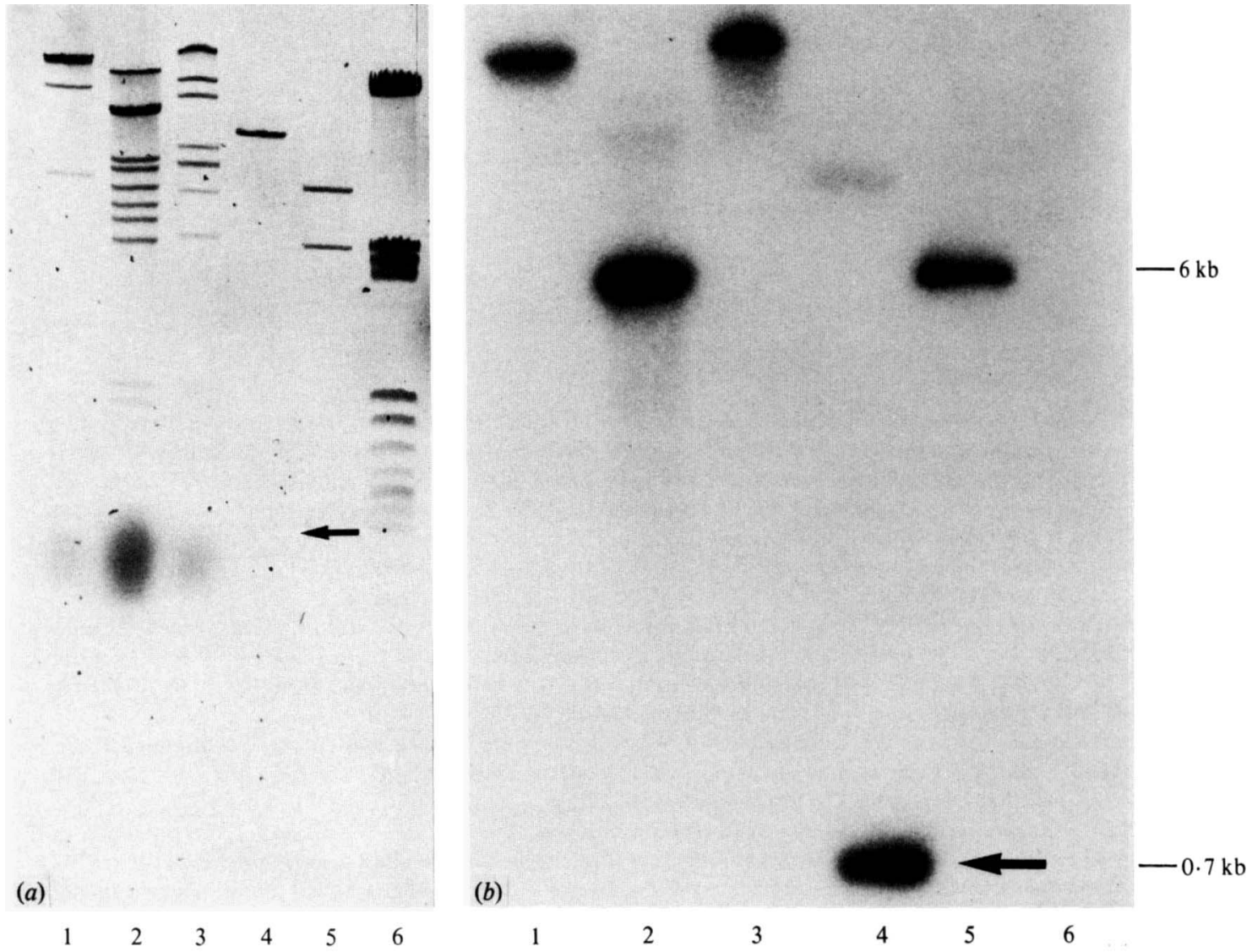

Fig. 1. The $t r a T$ gene probe is specific for IncF plasmids. The plasmids listed below were digested with the indicated endonuclease and the fragments thereby generated were separated by electrophoresis through an agarose gel $(a)$ and probed with the 700 bp BstEII fragment of pKT107 (autoradiograph of nitrocellulose filter shown in $b$ ) as described in Methods. 1, R386/HindIII; 2, R6-5/EcoRI; 3, R124/HindIII; 4, pKT107/BstEII; 5, pKT107/EcoRI; 6, R6K/HindIII. The arrows indicate the position of the $700 \mathrm{bp}$ BstEII fragment of pKT107.

Table 2. Distribution of traT-related sequences among Gram-negative clinical isolates

\begin{tabular}{lcll} 
Genus & $\begin{array}{c}\text { traT } T^{+} \text {strains/ } \\
\text { total strains } \\
\text { (percentage) }\end{array}$ & \multicolumn{1}{c}{ Genus } & $\begin{array}{c}\text { tra } T^{+} \text {strains/ } \\
\text { total strains } \\
\text { (percentage) }\end{array}$ \\
Shigella & $8 / 23^{*}(35)$ & Pseudomonas & $0 / 31(<3)$ \\
Salmonella & $20 / 63 \dagger(32)$ & Aeromonas & $0 / 66(<2)$ \\
Klebsiella & $15 / 69 \ddagger(22)$ & Plesiomonas & $0 / 33(<3)$ \\
Enterobacter & $0 / 12(<8)$ & Citrobacter & $0 / 7(<14)$ \\
Proteus & $0 / 5(<20)$ & Serratia & $0 / 4(<25)$ \\
Acinetobacter & $0 / 3(<33)$ & Yersinia & $0 / 10(<10)$
\end{tabular}

* $2 / 2$ dysenteriae $1,0 / 2$ dysenteriae (other serotypes), 2/2 schmitz, 1/2 sonnei, 1/6 boydii, 0/2 flexneri, $2 / 7$ undefined species.

†19/20 typhimurium, 1/2 dublin, $0 / 1$ hato, $0 / 1$ derby, $0 / 1$ essen, $0 / 1$ agona, $0 / 3$ infantis, $0 / 2$ subgenus I, $0 / 1$ othmarshen, $0 / 2$ enterididis, $0 / 29$ undefined species.

$\ddagger 13 / 58$ pneumoniae, $1 / 6$ oxytoca, $1 / 5$ undefined. 


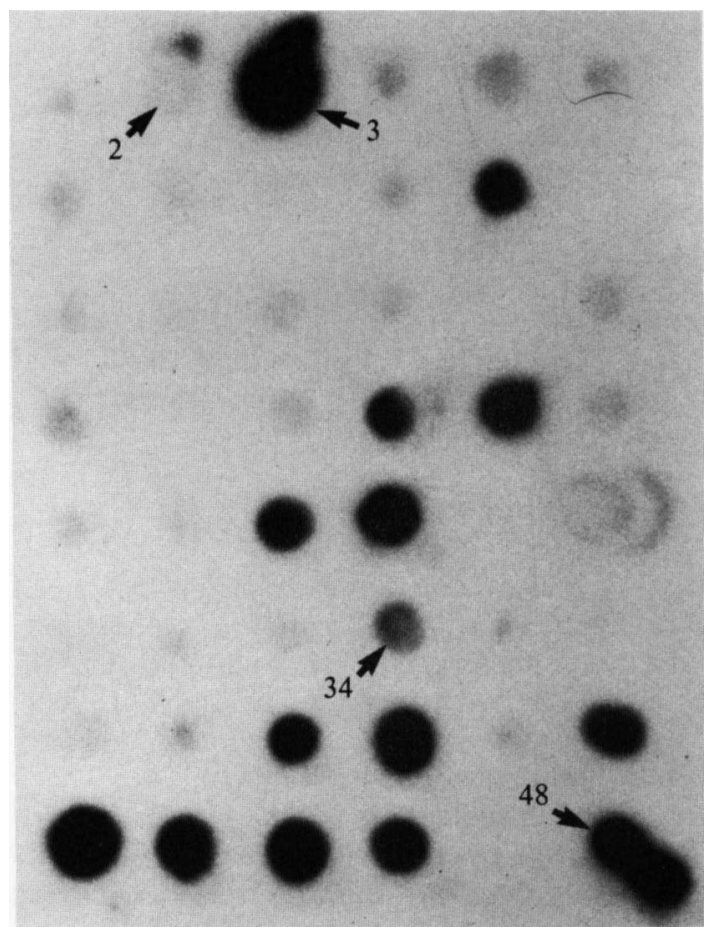

Fig. 2. Colony hybridization of isolates of $E$. coli with the traT gene probe. Control colonies are $E$. coli strains: C600 (2), C600(R6-5) (3) and C600(pKT107) (48) (Timmis et al., 1978; Moll et al., 1980). All dark spots on the autoradiogram were considered to be positive for the probe, whereas the lighter spot (34) was considered to be a weak but specific positive reaction.

with the fact that IncF plasmids exhibit narrow host range specificities, and that their propagation is therefore limited to some members of the family Enterobacteriaceae.

\section{Distribution of traT related sequences in isolates of $E$. coli}

Colonies of $680 \mathrm{E}$. coli strains from different clinical specimens and different geographical origins were analysed by hybridization with the ${ }^{32} \mathrm{P}$-labelled $t r a T$ gene probe; for comparison 113 strains isolated from stools of healthy individuals were also analysed. Each group of strains was analysed on at least two separate occasions. An autoradiograph of one filter after hybridization is shown in Fig. 2. Among the colonies giving a positive reaction, signals of different strength could be distinguished. These differences could be due to different colony sizes, different cellular copy numbers of the traT gene in different strains, or different degrees of homology to the probe.

Table 3 summarizes the results of the analysis. The frequency of $E$. coli isolates that hybridized to the $\operatorname{traT}$ probe was markedly higher if they originated from blood cultures (sepsis; $50-67 \%$ ) than if they were obtained from faeces of healthy individuals $(23-38 \%)$. Of $119 \mathrm{E}$. coli strains isolated from blood cultures in Mainz, $54 \%$ hybridized with the traT probe, whereas only $38 \%$ of a comparably sized group of strains from faeces of healthy adults were positive. This observation is in good agreement with data obtained with an anti-TraT protein monoclonal antibody (BitterSuermann et al., 1984) that was used to screen, by immunoblotting of electrophoretically fractionated total cell proteins, the same population of strains; $56 \%$ of sepsis strains and $38 \%$ of faecal strains reacted with the antibody. A direct comparison of the results of the two methods with this population of strains revealed an almost complete correlation, i.e. strains that reacted with the anti-TraT protein antibody also hybridized to the $\operatorname{tra} T$ probe, and vice versa. Thus, $\operatorname{traT}$ genes identified by colony hybridization in natural isolates are expressed. 
Table 3. Frequency of traT-related sequences in clinical isolates of E. coli from diverse geographical origins

Values are percentages with the number of strains examined given in parentheses. Isolates were taken from the blood of bacteraemia/septicaemia patients, the urine of UTI patients, the faeces of donors with enteric infections (Stool-e) and the faeces of healthy donors (Stool-n).

\begin{tabular}{lcccc}
\multicolumn{1}{c}{ Origin } & Blood & Urine & Stool-e & Stool-n \\
Mainz & $54(119)$ & - & $62(24)$ & $38(100)$ \\
Berlin & $54(33)$ & $49(65)$ & - & $23(13)$ \\
Geneva & $50(52)$ & $33(60)$ & - & - \\
Freiburg & - & $58(48)$ & - & - \\
Banaras & - & - & $53(253)$ & - \\
New York & $60(10)$ & $28(7)$ & - & - \\
Boston & $67(9)$ & - & - & - \\
Mean values & $54(223)$ & $46(180)$ & $54(277)$ & $36(113)$
\end{tabular}

A similar frequency of occurrence of the traT gene was found in smaller samples of isolates from cases of sepsis $(54 \%)$ and from normal faecal strains $(23 \%)$ collected in Berlin. Although in the case of sepsis strains isolated in Geneva, New York and Boston no direct comparisons with control groups of normal faecal strains of the same geographical origins were possible, the frequencies of $\operatorname{traT}$ positives in each group $(50 \%, 60 \%$ and $67 \%$, respectively) were comparable to those of sepsis strains from Mainz and Berlin (Table 3).

A large geographical variation was observed in the frequencies of carriage of $\operatorname{traT}$ (from $28 \%$ to $58 \%$ ) by $E$. coli strains isolated from cases of UTI. Although this variation could be due to the existence of different populations of pathogens in the different geographical regions sampled, it is more likely to be due to variation in the frequencies of the type of strain analysed. All strains were obtained from positive urine cultures, but no information as to the type of infection caused was available. We might anticipate that invasive strains causing pyelonephritis would exhibit additional properties over and above those of strains causing lower urinary tract infections. Thus, clarification of the variation observed will require differentiation of the two types of strain which, in turn, will necessitate evaluation of clinical data of patients.

Of the $E$. coli strains isolated from cases of infantile diarrhoea in Mainz, $62 \%$ hybridized to the traT probe, a frequency comparable to that found for sepsis strains. A slightly lower, but still high, proportion of strains $(53 \%)$ isolated from patients with diarrhoea in Banaras were also traT positive (Table 3 ).

\section{The traT gene in clinical isolates is generally plasmid-borne}

Plasmid DNA was prepared by the procedure of Kado \& Lui (1981) from 43 isolates, mostly strains of $E$. coli, from different sources, and was analysed by Southern blotting. All of the $22 E$. coli isolates and four S. typhimurium, two Klebsiella and two Shigella isolates shown by colony hybridization to be traT positive contained large plasmids, and all of these plasmids hybridized to the probe (Fig. 3). Thus, at least in E. coli and probably also in S. typhimurium, Klebsiella and Shigella traT would seem to be exclusively a plasmid-borne gene. Of the remaining 20 traT negative isolates, only eight contained large plasmids and of course none of these hybridized to the probe.

\section{Lack of correlation of serum resistance and carriage of traT}

The ability of a selection of sepsis, UTI, and healthy stool isolates of $E$. coli to survive exposure to $50 \%$ normal rabbit serum was examined, and the relationship of the serum resistance property and carriage of the traT gene was analysed (Table 4). Serum resistance was found to occur at approximately the same frequencies as the carriage of the traT gene in these three groups of isolates, i.e. in $59 \%$ of sepsis strains, $40 \%$ of UTI strains, and $42 \%$ of isolates from normal stools. However, except for the relatively small population of UTI strains $(80 \%$ of the serum resistant isolates were $\operatorname{traT}^{+}$), there was not a high degree of correlation between the serum resistance property and production of TraT protein; only $58 \%$ of serum resistant sepsis strains were concomitantly $\operatorname{traT}^{+}$. 

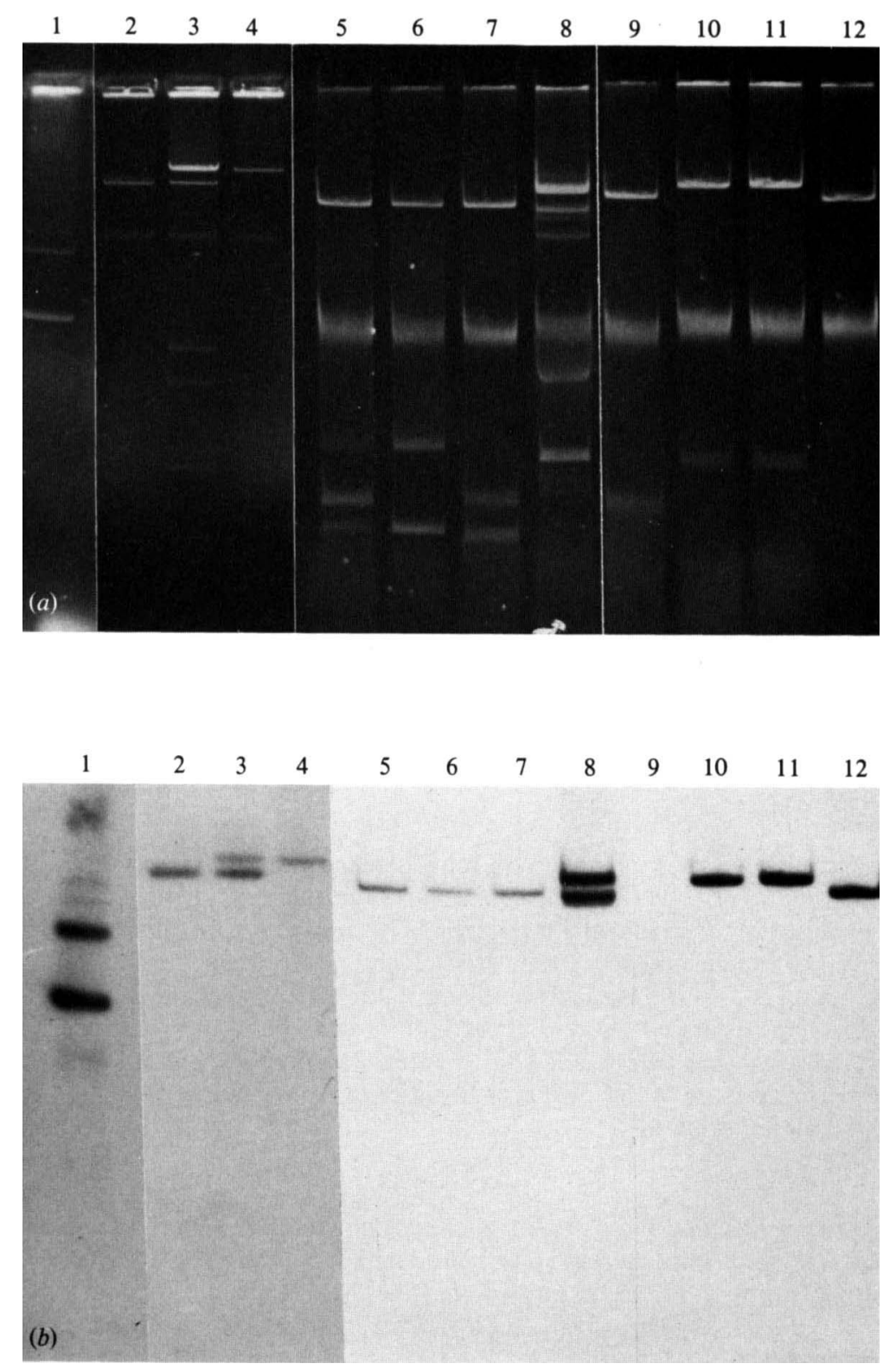

Fig. 3. Southern blot analysis of plasmid preparations from clinical isolates of $E$. coli, Salmonella typhimurium, Klebsiella and Shigella. Plasmid DNA was prepared from the strains listed below, subjected to electrophoresis on a $0.7 \%$ agarose gel $(a)$ and blotted and hybridized to the $\operatorname{tra} T$ gene probe (b), as described in Methods. All isolates were traT positive, as determined in the colony hybridization experiments described in the text. 1, E. coli C600 (pK T107) (control); 2, E. coli B2946-I (sepsis); 3, E. coli B2946-II (sepsis); 4, E. coli B3011 (sepsis); 5, S. typhimurium 4389/82 (sepsis); 6, S. typhimurium 5019/82 (sepsis); 7, S. typhimurium 3977/83 (diarrhoea); 8, Klebsiella 15 (diarrhoea); 9, Klebsiella 39 (diarrhoea); 10, Shigella 82 (diarrhoea); 11, Shigella 83 (diarrhoea); 12, E. coli C600 (R6-5) (control; Moll et al., 1980). Hybridization to the Klebsiella 39 plasmid (lane 9) was weak, though reproducible, and detectable only on the original autoradiograms but not on prints made from them. 
Table 4. Frequency of resistance to serum and of traT-related sequences in clinical isolates of E. coli

Isolates were taken from the blood of bacteraemia/septicaemia patients at Mainz and New York, the urine of UTI patients at New York and Freiburg and from faeces of healthy donors in Mainz.

$\begin{array}{cccc}\begin{array}{c}\text { Source of } \\ \text { isolate }\end{array} & \begin{array}{c}\text { No. of } \\ \text { strains }\end{array} & \begin{array}{c}\text { Percentage } \\ \text { serum } \\ \text { resistant }\end{array} & \begin{array}{c}\text { Percentage of total } \\ \text { serum } \\ \text { resistant } \\ \text { and } \text { traT }\end{array} \\ \text { Blood } & 58 & 59 & 34 \\ \text { Urine } & 25 & 40 & 32 \\ \text { Stools } & 50 & 42 & 16\end{array}$

Table 5. Frequency of pathogenicity-related characters in $139 \mathrm{E}$. coli isolates from cases of sepsis

\begin{tabular}{lcc}
\multicolumn{1}{c}{ Character* } & $\begin{array}{c}\text { No. of isolates } \\
\text { (percentage) }\end{array}$ & $\begin{array}{c}\text { No. of } t r a T \\
\text { isolates (percent }\end{array}$ \\
ColV plasmid & $27(19.4)$ & $21(77.8)$ \\
R plasmid & $133(95 \cdot 7)$ & $69(51.9)$ \\
K1 antigen & $20(14.4)$ & $15(75)$ \\
Haemolysin & $28(20 \cdot 1)$ & $7(25)$
\end{tabular}

* Presence of ColV plasmids was detected as production of colicin V, and of $\mathrm{R}$ plasmids as the presence of a
transferable antibiotic resistance plasmid.
+ Percentage of the isolates positive for the indicated character that also hybridized to the traT gene probe.

Association of traT, ColV and Kl antigen in E. coli strains isolated from cases of sepsis

Possible associations of the traT gene with $\mathrm{K} 1$ capsular antigen, haemolysin, and ColV and $\mathrm{R}$ plasmids in 139 isolates of $E$. coli from cases of sepsis were analysed (Table 5); $96 \%$ of the strains carried R plasmids, $19 \%$ carried ColV plasmids, $20 \%$ produced haemolysin and $14 \%$ produced the $\mathrm{K} 1$ capsule. Although no association of $\operatorname{traT}$ and haemolysin production or $\mathrm{R}$ plasmid carriage was found $(25 \%$ of the haemolysin positive strains and $52 \%$ of the R plasmid positive strains were $\left.\operatorname{traT} T^{+}\right)$, a high correlation between, on the one hand, $\operatorname{traT}$ and ColV $(78 \%$ of the ColV positive isolates were $\left.\operatorname{traT}^{+}\right)$and, on the other, $\operatorname{traT}$ and $\mathrm{K} 1$ production $\left(75 \%\right.$ of $\mathrm{K} 1^{+}$ isolates were $\operatorname{traT}^{+}$) was observed (see also Bitter-Suermann et al., 1984).

\section{DISCUSSION}

The IncF plasmid-specified TraT protein has been shown to confer upon selected strains of $E$. coli three properties that could increase their pathogenic potential, namely increased resistance to serum killing (Timmis et al., 1979; Moll et al., 1980), increased resistance to phagocytosis by peritoneal macrophages (Agüero et al., 1984), and increased virulence for a mouse infection model (L. DeLuca \& F. C. Cabello, unpublished observations). This protein is therefore a putative virulence factor of $\mathrm{traT}^{+}$strains of bacteria. In this study, by means of colony hybridization with a $700 \mathrm{bp}$ fragment containing most of the traT gene of plasmid R6-5, we have analysed the prevalence of the $t r a T$ gene in a variety of Gram-negative bacteria, particularly $E$. coli, isolated from clinical specimens.

The $\operatorname{traT}$ gene, which was shown to be carried exclusively on IncF plasmids, was found in $23-$ $67 \%$ of E. coli isolates, in $95 \%$ of Salmonella typhimurium isolates, and in $35 \%$ of Shigella and $22 \%$ of Klebsiella isolates, but not in several other types of Gram-negative bacteria, including most other salmonellae. This is consistent with the known narrow host range property of IncF plasmids. Interestingly, studies with an anti-TraT protein monoclonal antibody (BitterSuermann et al., 1984; Jürs et al., 1985) revealed not only the presence of TraT protein in nearly all isolates of $E$. coli and $S$. typhimurium that were shown by colony hybridization to carry traT, 
but also the presence of anti-TraT protein antibody-reacting proteins in $91 \%$ of isolates of Enterobacter cloacae and in $31 \%$ of isolates of non-typhimurium serotypes of Salmonella, neither group of which showed homology to the traT gene probe. The TraT-related proteins of these two latter groups of bacteria have, however, higher molecular weights than that of the TraT protein itself and may, except for the antibody-reacting epitope, be structurally distinct.

Within $E$. coli isolates, $54 \%$ of those from cases of bacteraemia/septicaemia, $54 \%$ of those from cases of enteric disease, and $36 \%$ of those from faeces of healthy individuals were found to carry traT. Thus, although traT is found in a relatively high proportion of isolates not associated with human disease, it is present in a markedly higher proportion of pathogenic strains. Carriage of the $\operatorname{traT}$ gene is thus correlated with pathogenicity of $E$. coli.

The $\mathrm{K} 1$ capsular antigen and ColV plasmids have been demonstrated in several studies to contribute significantly to the pathogenic potential of $E$. coli strains (e.g. see discussion in Timmis et al., 1985). It is interesting to note that possession of the traT gene is highly associated with both of these characters. Although its association with ColV plasmids, which belong to incompatibility group IncF, is readily understandable, the basis of its association with the $\mathrm{K} 1$ antigen is not so apparent. Perhaps this association indicates an involvement of the TraT protein or some other product of IncF plasmids in the virulence of $\mathrm{K} 1$ strains. In any case, it would seem that the traT gene may serve as a useful marker for some aspect of virulence that is characteristic of the sub-population of pathogenic strains that have the $\mathrm{K} 1$ and ColV properties.

Surprisingly, there was not a high degree of correlation of $\operatorname{traT}$ and serum resistance; although $59 \%$ of $E$. coli isolates from cases of sepsis were serum resistant, only $34 \%$ were concomitantly $\operatorname{traT}^{+}$and serum resistant (i.e. $58 \%$ of serum resistant isolates were $\operatorname{traT} T^{+}$). At present we do not know if an association exists between traT gene carriage and resistance to phagocytosis, the second virulence-associated property of TraT protein, and this aspect is currently under investigation.

In conclusion, if TraT protein does play a role in the pathogenesis of some invasive pathogens, another cell surface component must fulfil an analogous function in others. Moreover, if the role of TraT protein in pathogenesis is to mediate resistance to complement, it obviously does not manifest this property in certain isolates, namely those serum sensitive strains that are $\operatorname{traT}^{+}$. In order to determine conclusively whether or not the TraT protein plays a significant role in the pathogenesis of $t r a T^{+}$invasive strains of $E$. coli, it will be necessary to generate isogenic pairs of such strains differing only in the TraT character, and to compare their virulence in appropriate animal infection models. Suitable deletion mutant derivatives of traT-carrying plasmids were recently generated (D. O'Connor, unpublished) and are currently being used to this end.

We thank K. B. Jann (Freiburg), S. Levy (Boston), J. Wagner (Berlin), B. Hirschel and R. Auchenthaler (Geneva), and N. Datta (London) for generously providing reference strains and clinical isolates. This work was supported by grants from the Fonds National Suisse (to K.N.T.), the Bundesministerium für Forschung und Technologie, Bonn (to D. B.-S.), and the National Institutes of Health, USA (to F.C.C.).

\section{REFERENCES}

AChtman, M., Kennedy, N. \& Skurray, R. (1977). Cell-cell interactions in conjugating Escherichia coli: role of $t r a T$ protein in surface exclusion. Proceedings of the National Academy of Sciences of the United States of America 74, 5104-5108.

Achtman, M., Kusecek, B. \& Timmis, K. N. (1978). tra cistrons and proteins encoded by the Escherichia coli antibiotic resistance plasmid R6-5. Molecular and General Genetics 163, 169-179.

Agüero, M. E. \& Cabello, F. C. (1983). Relative contribution of ColV plasmid and $\mathrm{Kl}$ antigen to the pathogenicity of Escherichia coli. Infection and Immunity 40, 359-368.

agüero, M. E., Harrison, H. \& Cabello, F. C. (1983). Increased frequency of ColV plasmids and mannose-resistant haemagglutinating activity in Escherichia coli $\mathrm{K} 1$ population. Journal of Clinical Microbiology 18, 1413-1416.

AgüEro, M. E., Aron, L., Deluca, A. G., Timmis, K. N. \& Cabello, F. C. (1984). A plasmid-encoded outer membrane protein, TraT, enhances resistance of Escherichia coli to phagocytosis. Infection and Immunity 46, 740-746.

Andres, I., Slocombe, P. M., Cabello, F. C., Timmis, J. K., Lurz, R., BurkardT, H. J. \& Timmis, K. N. (1979). Plasmid replication functions. II. Cloning analysis of the rep $A$ replication region of the antibiotic resistance plasmid R6-5. Molecular and General Genetics 168, 1-25.

Binns, M. M., Davies, D. L. \& Hardy, K. G. (1979). 
Cloned fragments of the plasmid ColV,I-K94 specifying virulence and serum resistance. Nature, London 279, 778-781.

Bitter-Suermann, D., Peters, H., Jürs, M., Nehrbass, R., Montenegro, M. A. \& Timmis, K. N. (1984). Monoclonal antibody detection of IncF group plasmid-encoded TraT protein in clinical isolates of Escherichia coli. Infection and Immunity 46, 308-313.

Dretzen, G., Bellard, M., Sarsone-Corsi, P. \& Chambon, P. (1981). A reliable method for the recovery of DNA fragments from agarose and polyacrylamide gels. Analytical Biochemistry 112, 295-298.

Gemski, P., Cross, A. S. \& Sadoff, J. C. (1980). K1 antigen-associated resistance to the bactericidal activity of serum. FEMS Microbiology Letters 9, 193-197.

Goldman, R. C., Joiner, K. \& Leive, L. (1984). Serum-resistant mutants of Escherichia coli 0111 contain increased lipopolysaccharide, lack an $\mathbf{O}$ antigen-containing capsule, and cover more of their lipid A core with $\mathrm{O}$ antigen. Journal of Bacteriology 159, 877-882.

Grunstein, M. \& Hogness, D. S. (1975). Colony hybridization: a method for the isolation of cloned DNAs that contain a specific gene. Proceedings of the National Academy of Sciences of the United States of America 72, 3961-3965.

Hildebrandt, J. F., Mayer, L. W., Wang, S. P. \& Buchanan, T. M. (1978). Neisseria gonorrhoeae acquire a new principal outer-membrane protein when transformed to resistance to serum bactericidal activity. Infection and Immunity 20, 267-273.

Joiner, K. A., Hammer, C. H., Brown, E. J., Cole, R. J. \& Frank, M. M. (1982). Studies on the mechanism of bacterial resistance to complement-mediated killing. I. Terminal complement components are deposited and released from Salmonella minnesota S218 without causing bacterial death. Journal of Experimental Medicine 155, 797-808.

Jürs, M., Peters, H., Timmis, K. N. \& BitterSuermanN, D. (1985). Immunoblotting with monoclonal antibodies - a highly specific system for detection and identification of bacterial outer membrane proteins. In Proceedings of the Fourth International Symposium on Rapid Methods and Automation in Microbiology and Immunology. Edited by K. O. Habermehl. Berlin: Springer Verlag (in the Press).

KADO, C. J. \& LUI, S. T. (1981). Rapid procedure for detection and isolation of large and small plasmids. Journal of Bacteriology 145, 1365-1373.

Manning, P. A., Beutin, L. \& Achtman, M. (1980). Outer membrane of Escherichia coli: properties of the $\mathrm{F}$ sex factor $\mathrm{traT}$ protein which is involved in surface exclusion. Journal of Bacteriology 142, 285-294.

McCabe, W. R., Kaijser, B., Olling, S., Uwaydah, M. \& HANSON, L. A. (1978). Escherichia coli in bacteremia: $K$ and $O$ antigens and serum sensitivity of strains from adults and neonates. Journal of Infectious Diseases 138, 33-41.

Moll, A., Cabello, F. C. \& Timmis, K. N. (1979). Rapid assay for the determination of bacterial resistance to the lethal activity of serum. FEMS Microbiology Letters 6, 273-276.

Moll, A., Manning, P. A. \& Timmis, K. N. (1980).
Plasmid-determined resistance to serum bactericidal activity: a major outer membrane protein, the $\operatorname{traT}$ gene product, is responsible for plasmid-specified serum resistance in Escherichia coli. Infection and Immunity 28, 359-367.

Moseley, S. L., HuQ, I., Alim, A .R. M. A., So, M., Samadpour-Motalebi, M. \& Falkow, S. (1980). Detection of enterotoxigenic Escherichia coli by DNA colony hybridization. Journal of Infectious Diseases 142, 892-898.

Munn, C. B., Ishiguro, E. E., Kay, W. W. \& Trust, T. J. (1982). Role of surface components in serum resistance of virulent Aeromonas salmonicida. Infection and Immunity 36, 1069-1075.

Ogata, R. T., Winters, C. \& Levine, R. P. (1982). Nucleotide sequence analysis of the complement resistance gene from plasmid R100. Journal of Bacteriology 151, 819-827.

Perumal, N. B. \& Minkley, E. G., JR (1984). The product of the $F$ sex factor traT surface exclusion gene is a lipoprotein. Journal of Biological Chemistry 159, 5357-5360.

Rigby, P. W. J., Dieckmann, M., Rhodes, C. \& Berg, P. (1977). Labelling deoxyribonucleic acid to high specific activity in vitro by nick translation with DNA polymerase I. Journal of Molecular Biology 113, 237-251.

Roantree, R. J. \& Rantz, L. A. (1960). A study of the relationship of the normal bactericidal activity of human serum to bacterial infection. Journal of Clinical Investigation 39, 72-81.

Southern, E. M. (1975). Detection of specific sequences among DNA fragments separated by gel electrophoresis. Journal of Molecular Biology 89 , 503-517.

TAYLOR, P. W. (1976). Immunochemical investigations on lipopolysaccharides and acidic exopolysaccharides from serum-sensitive and serum-resistant strains of Escherichia coli isolated from urinary tract infections. Journal of Medical Microbiology 9, 405421.

TAYLOR, P. W. (1983). Bactericidal and bacteriolytic activity of serum against Gram-negative bacteria. Microbiological Reviews 47, 46-83.

Timmis, K. N., Cabello, F. C. \& Cohen, S. N. (1978). Cloning and characterization of EcoRI and Hindlll restriction endonuclease-generated fragments of antibiotic resistance plasmids R6-5 and R6. Molecular and General Genetics 162, 121-137.

Timmis, K. N., Moll, A. \& Danbara, H. (1979). Plasmid gene that specifies resistance to the bactericidal activity of serum. In Plasmids of Medical, Environmental and Commercial Importance, pp. 145153. Edited by K. N. Timmis \& A. Pühler. Amsterdam: Elsevier/North Holland Biomedical Press.

Timmis, K. N., Manning, P. A., Echarti, C., Timmis, J. K. \& Moll, A. (1981). Serum resistance in E. coli. In Molecular Biology, Pathogenicity and Ecology of Bacterial Plasmids, pp. 134-144. Edited by S. B. Levy, R. C. Clowes \& E. L. Koenig. New York: Plenum Publishing Corporation.

Timmis, K. N., Boulnois, G. J., Bitter-SuermanN, D. \& Cabello, F. C. (1985). Surface components of Escherichia coli that mediate resistance to the bactericidal activities of serum and phagocytes. 
Current Topics in Microbiology and Immunology (in the Press).

Vostı, K. L. \& Randall, E. (1970). Sensitivity of serologically classified strains of Escherichia coli of human origin to the serum bactericidal system. American Journal of Medical Sciences 259, 114-119.
Williams Smith, H. (1974). A search for transmissible pathogenic characters in invasive strains of Escherichia coli: the discovery of a plasmid-controlled toxin and a plasmid-controlled lethal character closely associated, or identical, with colicin V. Journal of General Microbiology 83, 95-111. 